\title{
Lignin biodegradation with laccase-mediator systems
}

\author{
Lew Paul Christopher ${ }^{1,2 *}$, Bin Yao ${ }^{1}$ and Yun $\mathrm{Ji}^{3}$ \\ ' Center for Bioprocessing Research and Development, South Dakota School of Mines \& Technology, Rapid City, SD, USA \\ 2 Department of Civil and Environmental Engineering, South Dakota School of Mines \& Technology, Rapid City, SD, USA \\ ${ }^{3}$ Department of Chemical Engineering, University of North Dakota, Grand Forks, ND, USA
}

Edited by:

Soo-Jeong Shin, Chungbuk National

University, South Korea

Reviewed by:

Sulaiman Al-Zuhair, United Arab

Emirates University, United Arab

Emirates

Luis Serrano, University of the

Basque Country, Spain

*Correspondence:

Lew Paul Christopher, Center for Bioprocessing Research and

Development, South Dakota School

of Mines \& Technology, 501 E. Saint

Joseph Street, Rapid City, SD 57001

USA

e-mail: lew.christopher@sdsmt.edu
Lignin has a significant and largely unrealized potential as a source for the sustainable production of fuels and bulk high-value chemicals. It can replace fossil-based oil as a renewable feedstock that would bring about socio-economic and environmental benefits in our transition to a biobased economy. The efficient utilization of lignin however requires its depolymerization to low-molecular weight phenolics and aromatics that can then serve as the building blocks for chemical syntheses of high-value products. The ability of laccase to attack and degrade lignin in conjunction with laccase mediators is currently viewed as one of the potential "breakthrough" applications for lignin valorization. Here, we review the recent progress in lignin biodegradation with laccase-mediator systems, and research needs that need to be addressed in this field.

Keywords: lignin, biodegradation, laccase, mediator, laccase-mediator systems, lignin model compounds

\section{INTRODUCTION}

Lignocellulosic biomass is the single renewable resource on earth, reproduced at 60 billion tons as organically bound carbon per year, which has the potential to create a sustainable energy future. In their "billion ton vision," the U.S. Department of Energy (DOE) reported that nearly 1.3 billion dry tons of plant biomass could become available to produce biofuels and displace more than $30 \%$ of the nation's consumption of liquid transportation fuels (Perlack et al., 2005). Lignin removal from biomass helps enhance the efficiency of cellulose and hemicellulose hydrolysis, and therefore, facilitates the utilization of the carbohydrate portion of biomass in production of cellulosic ethanol and other biofuels (Siqueira et al., 2012). Annually, about 50-60 million tons of lignin are produced by the pulp and paper industry alone. The amount of available lignin is expected to further increase as a result of the recent biorefinery developments aimed at replacing fossil feedstocks with lignocellulosic biomass for biofuel production. A recent DOE report estimates that 0.225 billion tons of lignin (biorefinery lignin) could be produced from processing 750 million tons of biomass feedstock to biofuel (Bozell et al., 2007). However, the commercial use of lignin is limited to only $2 \%$ of its availability with the rest (Gosselink et al., 2004) usually burned to provide steam and process heat for the pulp and paper mills. It has been reported that lignin used as a low cost fuel has a value of only $\$ 0.18 / \mathrm{kg}$ whereas its value as a chemical feedstock is about sixfold higher (Macfarlane et al., 2009). Since existing lignin products are currently based primarily on low-value lignosulfonates (approximately 1 million tons) and kraft lignins (100,000 tons), lignin markets are stagnated at $\$ 300$ million per year with very low growth rates (United Nations, 2012).

Therefore, new methods for lignin deconstruction and utilization for value-added products, other than just simply burning it as a solid fuel, are needed. Due to the complex cross-linked three-dimensional network structure, lignin is highly rigid and recalcitrant to degradation (Ruiz-Dueñas and Martínez, 2009). There are two alternative paths for the breakdown of the lignin polymer - chemical and biological. A distinct advantage of the biological approach is the lack of yield loss associated with the thermal decomposition of lignin, and the opportunity to "direct" lignin biodegradation utilizing selective lignolytic microorganisms and enzymes, thereby avoiding the formation of undesirable by-products. In addition, the biocatalytic process takes place under mild conditions that lowers the energy input and reduces the environmental impact. In nature, efficient and selective lignin biodegradation is mediated mainly by white-rot fungi and certain bacteria (Baldrian, 2006). The lignolytic enzymes are classified as peroxidases (lignin, manganese, and versatile peroxidase) and laccases. The broad substrate specificity of laccases and their ability to utilize atmospheric oxygen as electron donor instead of hydrogen peroxide used by peroxidases makes these enzymes a promising candidate for diverse industrial applications. These include use as a bleaching agent in pulp delignification, as a stabilizer in wine production, in detoxification of wastewaters and organic pollutants, in textile decolorization, biofuel cells and biosensors, manufacture of antibiotics and anti-cancer drugs, polymer and fiber surface modifications, etc. (Couto and Herrera, 2007; Medhavi and Lele, 2009). Among these applications, the ability of laccase to attack and degrade lignin in conjunction with laccase mediators is currently viewed as one of the potential "breakthrough" applications that are expected to offer great opportunities for lignin valorization. Here, we review the potential of laccase-mediator systems (LMS) for lignin biodegradation with related challenges and opportunities that currently exist.

\section{LIGNIN}

Lignin is most abundant naturally occurring aromatic polymer and following cellulose, the second most abundant organic 
polymer on earth. It comprises $20-35 \%$ of the dry weight of plant cell wall, depending on the biomass source (Galbe and Zacchi, 2007). Softwoods generally contain more lignin (2535\%) than hardwoods (20-25\%) (Faravelli et al., 2010). Lignin is predominantly concentrated in the middle lamella and primary cell wall. It surrounds and crosslinks the cellulose-hemicellulose matrix through lignin-carbohydrate network structures that provide stiffness to the cell walls and glue the cells together thereby shielding the polysaccharides against microbial degradation. As a hydrophobic polymer, lignin also serves as a barrier against water penetration. All these biological functions of lignin make this unique biopolymer one of the most recalcitrant naturally occurring compound (Ruiz-Dueñas and Martínez, 2009). The lignin macromolecule contains functional groups such as methoxyl, phenolic hydroxyl, alcoholic hydroxyl, and carbonyl groups that have a profound impact on its reactivity.

Lignin is composed of phenylpropanoid units, known as monolignols or lignin precursors, which are linked together through carbon-carbon and carbon-oxygen bonds with a varying degree of methoxylation (Adler, 1977; Karhunen et al., 1995) (Figure 1). The monolignols have been identified as $p$-coumaroyl, confineryl, and sinapyl alcohols, which are the respective precursors of $p$-hydrophenyl $(\mathrm{H})$, guaiacyl $(\mathrm{G})$, and syringyl $(\mathrm{S})$ units in lignin (Zhang et al., 2003). Usually, plant cell wall lignification is accomplished through oxidative coupling and chemically controlled polymerization of the three lignin precursors in different proportions. For example, softwood lignin is built up mainly from
G-units (up to 95\%) with small amounts of $\mathrm{H}$-units, whereas hardwood lignin has both S- and G-units in proportions from 1:1 to $1: 3$, with traces of $\mathrm{H}$-units. All three lignin units are present in annual plants (Sjostrom, 1993; Brunow, 2001; Kang et al., 2012).

Lignin biosynthesis proceeds through oxidative coupling reactions of radicals generated by laccases and peroxidases that lead to formation of a growing polymer linked by carbon-carbon and ether bonds. The resonance-stabilized phenoxy radicals polymerize in a variety of monomer-oligomer and oligomer-oligomer coupling combinations through $\beta-O-4, \alpha-O-4, \beta-5, \beta-1, \beta-\beta, 5-5$, dibenzodioxocin, and 4-O-5 linkages, some of them depicted in Figure 2. The most abundant structure in lignin is the arylglycerol$\beta$-aryl ether structure with the $\beta$-O-4 linkages accounting for up to $60 \%$ of the total inter-unit bonds in lignin (Balakshin et al., 2009) whereas the carbon-carbon bonds in lignin are among the most resistant toward breakage (Capanema et al., 2004). However, it should be noted that despite the numerous studies on lignin that followed the pioneering work of Freudenberg and co-workers (Freudenberg and Hübner, 1952; Freudenberg, 1959, 1962, 1965; Freudenberg and Neish, 1968) more than six decades ago, its structure is still not completely understood.

\section{LACCASE-MEDIATOR SYSTEMS LACCASE}

Laccase (benzenediol oxygen oxidoreductase, EC 1.10.3.2) is a copper-containing phenol oxidase, which can oxidize electron-rich substrates of phenolic and non-phenolic origin with

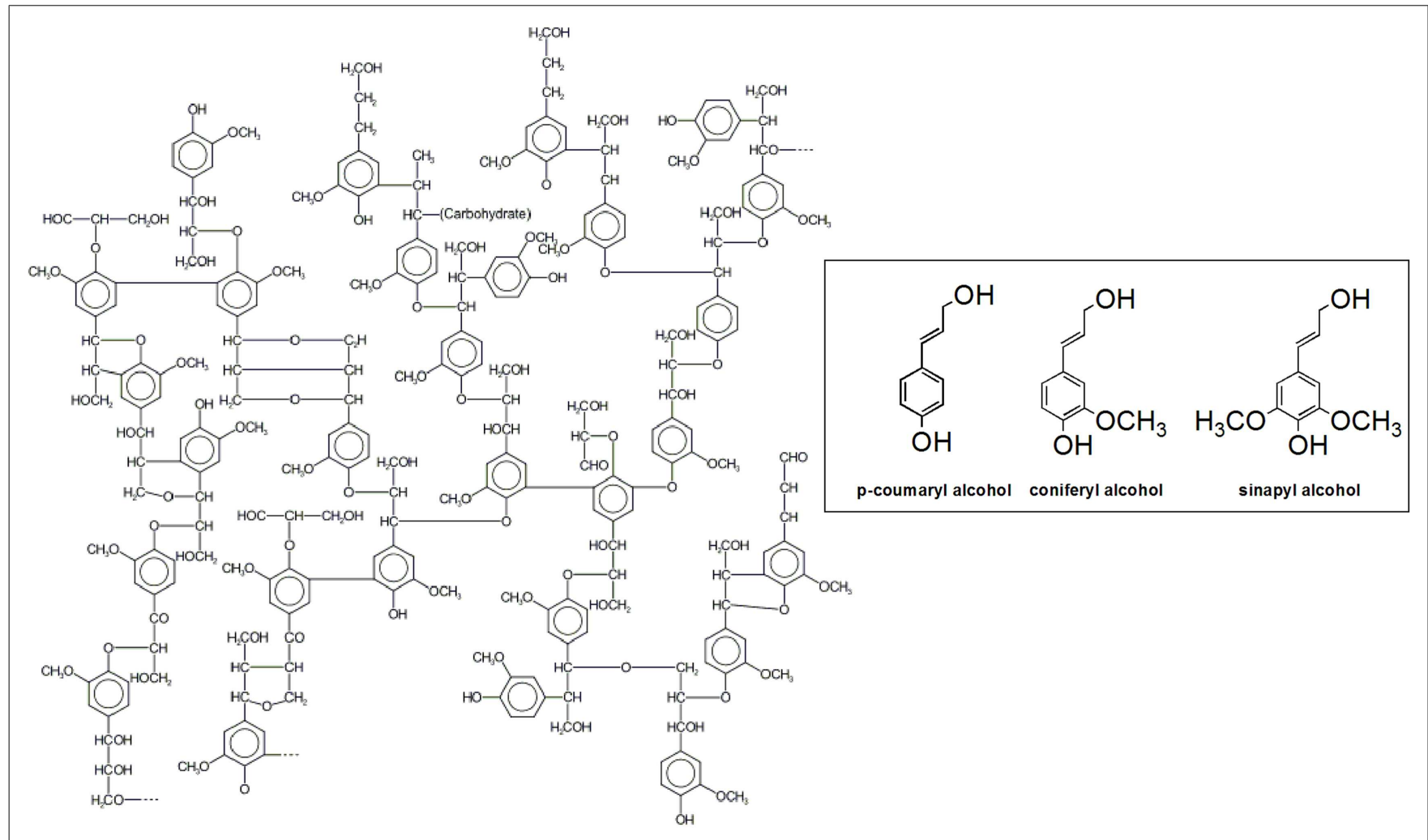

FIGURE 1 | Structure of lignin and lignin precursors of H-, G-, and S-units in lignin 
<smiles>[R]Oc1c([R4])cc([R6])cc1Oc1c([R])cc([R])cc1[R]</smiles>

1

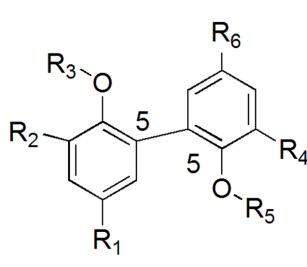

2<smiles>[R]Oc1c([R])cc(CC(CO)c2cc([R])c(O[R])c([R])c2)cc1[R6]</smiles>

3

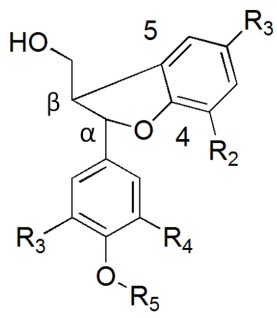

4<smiles>[R]Oc1c([R])cc(C[C@H](CO)Oc2c([R3])cc([R])cc2[R])cc1[R]</smiles>

FIGURE 2 | Commonly found linkages in lignin: (1) 4-O-5; (2) 5-5; (3) $\beta-1$; (4) $\beta-5$; (5) $\beta-O-4$

a concomitant reduction of oxygen to water through a radicalcatalyzed reaction mechanism (Bourbonnais et al., 1997). The functions of laccases are diverse. They are involved in both lignin biosynthesis and lignin degradation, pigment formation in fungal spores, plant pathogenesis, and as fungal virulence factors, in iron metabolism and kernel browning processes in plants (Hood et al., 2003; Higuchi, 2004; Hoopes and Dean, 2004; Zhu and Williamson, 2004). Laccase was first discovered in the Japanese lacquer tree Rhus vernicifera in the nineteenth century (Yoshida, 1883). Although laccases are present in higher plants, fungi, bacteria, and insects, the most studied group of enzymes to date is from fungal origin, including the genera of Ascomycetes, Deuteromycetes, Basidiomycetes, and cellulolytic fungi (Hatakka, 1994; Schneider et al., 1999; Pandey et al., 2001; Baldrian, 2006; Sharma et al., 2007). Among these, laccases from the white-rot basidiomycetes (white-rot fungi) such as Trametes (Coriolus) versicolor, T. hirsuta, T. ochracea, T. villosa, T. gallica, Phlebia radiata, Coriolopsis polyzona, Lentinus edodes, Pleurotus ostreatus, Pycnoporus cinnabarinus, Coprinus cinereus, etc., are most frequently described and reported (Baldrian, 2006). The first characterized ascomycete enzyme was from Monocillium indicum (Thakker et al., 1992). Fungal laccases are responsible for detoxification, fructification, sporulation, phytopathogenicity, and lignin degradation (Widsten and Kandelbauer, 2008). White-rot fungi have a strong ability to degrade lignin due to the high laccase activity they produce, and to their well developed hyphal organization that can efficiently penetrate plant cell walls (Grove and Bracker, 1970).

Compared to fungal laccases, bacterial laccases are generally more stable at high $\mathrm{pH}$ and temperatures (Table 1). Whereas fungal laccases can be both intra- and extra-cellular, bacterial laccases are predominantly intracellular, such as Azospirillum lipoferum, Marinomonas mediterranea, and Bacillus subtilis (Rosconi et al., 2005; McMahon et al., 2007). To date, only three bacterial laccases have been completely purified and characterized (as opposed to more than 100 fungal laccases): (1) from the rhizospheric bacterium A. lipoferum (Givaudan et al., 1993); (2) from a melanogenic marine bacterium M. mediterranea (Solano et al., 1997); and (3) from the endospore coat component CotA of $B$. subtilis (Kim et al., 2006). Laccases from Streptomyces lavendulae (Nandan and Nampoothiri, 2014) and S. cyaneus (Teeradakorn et al., 1998) have also been reported. Bacterial laccases normally have a higher $\mathrm{pH}$ optimum than fungal laccases (Margot et al., 2013), with optimum $\mathrm{pH}$ being acidic for the latter (Table 1) (Dhakar and Pandey, 2013). Due to the intracellular physiological properties of plant laccases, their optimal $\mathrm{pH}$ is in the neutral range (Dwivedi et al., 2011; Pezzella et al., 2013). The isoelectric point of plant laccases (pI 9) is also higher than that of fungal laccases (pI 3-7). The optimal temperature for most laccases is between 50 and $70^{\circ} \mathrm{C}$ (Chefetz et al., 1998). Their thermal stability depends on the microbial source. For example, bacterial laccases are more thermostable than fungal laccases (Hildén et al., 2007). Plant laccases, on the other hand, are more glycosylated and have a greater molecular weight than fungal and bacterial laccases (Table 1). Laccase is a secondary metabolite produced under growth-limiting conditions (limited nitrogen in particular), which however has a negative impact on the enzyme yields (Gianfreda et al., 1999). Due to the low laccase activities in most native fungi and bacteria that preclude industrial uses, improved productivity through cloning of laccase genes and their heterologous expressing has been targeted. Bacterial laccases from B. subtilis, S. lavendulae, and Thermus thermophiles have been expressed in Escherichia coli (Martins et al., 2002). Hosts for the heterologous expression of fungal laccases include yeasts such as Saccharomyces cerevisiae (Bulter et al., 2003), fungi such as Trichoderma reesei (Kiiskinen et al., 2004) and Aspergillus oryzae (Sigoillot et al., 2004), and plants such as tobacco (LaFayette et al., 1999) and maize (Bailey et al., 2004). Laccases can be produced in both liquid and solid state fermentation (Mazumder et al., 2009). Copper (Palmieri et al., 2000), ethanol 
Table 1 | Properties of some bacterial, fungal, and plant laccases.

\begin{tabular}{|c|c|c|c|c|c|}
\hline Laccase & $T_{\text {opt }}\left({ }^{\circ} \mathrm{C}\right)$ & $\mathrm{pH}_{\text {opt }}$ & Mw (kDa) & Glycosylation (\%) & Reference \\
\hline \multicolumn{6}{|l|}{ BACTERIAL } \\
\hline Bacillus subtilis & 37 & 7.6 & 57.2 & ND & Phelan et al. (2013) \\
\hline Bacillus licheniformis & 40 & 7.0 & 64 & ND & Salkinoja-Salonen et al. (1999) \\
\hline Streptomyces griseus & 40 & 6.5 & 209 & ND & Leigh (1997) \\
\hline \multicolumn{6}{|l|}{ FUNGAL } \\
\hline Agaricus blazei & 20 & 5.5 & 66 & ND & Ullrich et al. (2005) \\
\hline Basidiomycota sp. & 80 & 4.5 & 64 & 6.5 & He and Li (2013) \\
\hline Melanocarpus albomyces & $60-70$ & 6.0 & 80 & ND & Berdy (2005) \\
\hline Trametes hirsuta & 45 & 4.5 & 70 & 12 & Shleev et al. (2004) \\
\hline Trametes versicolor & 50 & 3.0 & 67 & $10-12$ & Solomon et al. (1996) \\
\hline Trichophyton rubrum & 20 & 5.5 & 65 & ND & Yang et al. (2007) \\
\hline \multicolumn{6}{|l|}{ PLANT } \\
\hline Acer pseudoplatanus & 15.5 & 6.6 & 97 & $40-45$ & Sterjiades et al. (1996) \\
\hline Chaetomiaceae sp. & 60 & 7.0 & 77 & ND & Jiao et al. (2006) \\
\hline Rhus vernicifera & 25 & 7.0 & 110 & 45 & Messerschmidt and Huber (1990) \\
\hline
\end{tabular}

(Lee et al., 1999), and aromatic compounds such as ferulic acid, gallic acid, veratryl alcohol, anisidine, xylidine, syringaldazine, and lignosulfonates (Saraiva et al., 2012) serve as efficient inducers of laccase production.

Most laccases contain four copper atoms in their active site, which mediate the redox process and are classified in three groups according to their magnetic and spectroscopic properties (Messerschmidt and Huber, 1990). Figure 3 shows the three types of copper coordination in laccases: type 1 or blue copper center, type 2 or normal copper, and type 3 or coupled binuclear copper centers (Wong, 2009). Type 1 copper, coordinated with one cysteine, one methionine, and two histidine molecules (Palmieri et al., 2003), contributes to the intense blue color of laccase with a strong electron adsorption at $600 \mathrm{~nm}$. It is responsible for the substrate oxidation and redox potential of laccase. Type 2 copper coordinates with two histidines and a water molecule; it is colorless with no absorption in the visible spectrum (Piontek et al., 2002). There are three histidines as ligands to each type 3 copper atom, with anti-ferromagnetic coupling and a hydroxyl bridge between the copper pair that shows a weak UV absorbance at $330 \mathrm{~nm}$ (Piontek et al., 2002). The one type 2 and two type 3 copper atoms form a tri-nuclear center that catalyzes the fixation and reduction of oxygen to water. Enzyme stability is directly influenced by the hydrogen bonding and salt bridges that exist between the copper atoms (Hildén et al., 2009). All four copper atoms are fully oxidized $\left(\mathrm{Cu}^{2+}\right)$ in the native form of laccase. Because of that, laccase can decarboxylate, demethylate and demethoxylate phenolic, and methoxyphenolic acids, which are important initial steps in lignin degradation (d'Acunzo et al., 2002). Since laccase catalyzes one-electron oxidation of substrates, the transfer of four electrons from four laccase substrates via the type 1 copper to the tri-nuclear center with oxygen as the final electron acceptor represents one catalytic cycle of substrate oxidation and oxygen reduction. Based on the type 1-3 copper properties, laccases are categorized into enzymes with high $(0.6-0.8 \mathrm{~V})$ or low $(0.4-0.6 \mathrm{~V})$ redox potential (Gutiérrez et al., 2006). For example, the laccases secreted by the white-rot fungi T. versicolor and Neurospora grassa have a high redox potential of $0.78-0.80 \mathrm{~V}$ (Mikolasch and Schauer, 2009), whereas the redox potential of the laccases from $R$. vernicifera and C. cinereus are only $0.42 \mathrm{~V}$ (Reinhammar and Vänngåd, 1971) and $0.55 \mathrm{~V}$ (Schneider et al., 1999). The catalytic efficiency of laccases appears to be directly proportional to the redox potential of type 1 copper, which explains the increased interest in laccases with high redox potential ( $\mathrm{Xu}$ et al., 1996). Laccases occur as monomeric and polymeric glycoproteins, with most fungal laccases being reported as monomers, dimers, or tetramers. The first crystalline three-dimensional structure of a laccase from $T$. versicolor was published in 2002 (Piontek et al., 2002). The molecular mass of a monomeric laccase is typically in the range $60-110 \mathrm{kDa}$ with 10-50\% glycosylation (Table 1). The high carbohydrate content in the protein molecule is believed to provide thermostability to laccases of up to $70^{\circ} \mathrm{C}$ (Yaropolov et al., 1994). In addition, glycosylation impacts enzyme secretion and activity (Xu, 1999). Most white-rot fungi produce more than one laccase isozyme that differ in the degree of glycosylation, amino acid sequence, molecular weight, pI, and substrate specificity (Mansur et al., 2003).

It has been shown that small halide anions can inhibit the activity of laccase due to disturbance of the internal electron transfer of the type 2 and 3 copper atoms that coordinate these anions (Dwivedi et al., 2011). Some metal ions such as $\mathrm{Hg}^{2+}, \mathrm{Mg}^{2+}$, $\mathrm{Ca}^{2+}$, and $\mathrm{Zn}^{2+}$ also inhibit laccase activity by modifying the amino acid residues or causing conformational changes in the laccase glycoprotein. Fatty acids, sulfhydryl reagents, hydroxyglycine, dithiothreitol, and glutathione have also been reported as laccase inhibitors as the copper type 2 atoms are chelated by these organic compounds (Blanquez et al., 2004).

Laccases are able to oxidize not only various aromatic compounds such as substituted phenols, aminophenols, polyphenols, $o$ - and $p$-diphenols, polyamines, methoxy phenols, aryl diamines, aromatic amines, and thiols, but also some inorganic compounds such as iodine and ferrocyanide ions (Claus, 2003). The oxidation 
of inorganic ions is accompanied by a simultaneous reduction of dioxygen to water without intermediate production of hydrogen peroxide (Morozova et al., 2007a). The laccase-mediated formation of phenoxyl radicals results in cleavage of carbon-carbon and $\beta$-aryl bonds as well as aromatic rings in lignin (Bourbonnais et al., 1995; Kawai et al., 1999). Due to the low redox potential of laccases $(0.5-0.8 \mathrm{~V})$, laccase alone can only oxidize phenolic lignin structures and not the non-phenolic aromatic structure, which comprises more than $80 \%$ of lignin (Wong, 2009). Only a small group of peroxidases secreted by lignolytic fungi such as lignin peroxidase with a redox potential of 1.15-1.25 V (Ward et al., 2003) can oxidize the non-phenolic groups of lignin directly (del Pilar Castillo et al., 1997). Furthermore, permeability studies have indicated that molecules larger than $2 \mathrm{kDa}$ are unable to penetrate the pores in the plant cell walls (Srebotnik et al., 1988). However, in presence of low-molecular weight (LMW) chemical compounds mediators, that normally have a redox potential higher than $0.9 \mathrm{~V}$, the substrate range of laccase can be expanded to include oxidation of non-phenolic lignin. Therefore, the LMS play a key role in depolymerizing lignin (Schmidt, 2007).

\section{MEDIATORS}

A mediator is a small chemical compound that is continuously oxidized by the laccase enzyme and subsequently reduced by the substrate. As the substrate due to its size cannot enter the laccase active site, the mediator acts as a carrier of electrons between the enzyme and the substrate thereby overcoming the steric hindrances that exist between them (Li et al., 1999). The laccase reactivity decreases with the increase of the substrate size, therefore the limited substrate accessibility is overcome through the use of appropriate laccase mediators. In the initial reaction step, the mediator is oxidized to stable intermediates with high redox potential by laccase. Thereafter, following diffusion-controlled reaction kinetics, the oxidized mediator diffuses away from the enzyme, and due to its small size is able to penetrate the pores of the plant cell walls to reach the target substrate (Figure 4). As a result, the substrate (lignin, aromatic compounds, etc.) is oxidized by the intermediates that cannot be oxidized directly by laccase, while the oxidized mediator is reduced to its initial form (Call and Mücke, 1997). The ideal mediator should be non-toxic, economic, and efficient, with stable oxidized and reduced forms that do not inhibit the enzymatic reaction (Morozova et al., 2007b). Moreover, the redox mediator should be able to continuously maintain the cyclic redox conversion.

Bourbonnais and Paice (1990) first reported that in the presence 2,2'-azinobis(3-ethylbenzthiazoline-6-sulfonate) (ABTS), the laccases of $T$. versicolor can also oxidize non-phenolic lignin model compounds (LMCs) such as veratryl alcohol and 1-(3,4-dimethoxyphenyl)-2-(2-methoxyphenoxy)-propane1,3-diol to produce $\alpha$-carbonyl derivatives. The laccase-ABTS system was also able to demethylate and delignify kraft pulp (Bourbonnais et al., 1997). ABTS is readily oxidized by free radicals, various peroxidases and laccase to the cation radical $\mathrm{ABTS}^{+\bullet}$, and the concentration of the intensely colored, green-blue cation radical can be correlated to the enzyme activity. The cation radical can be oxidized further to the dication $\left(\mathrm{ABTS}^{2+}\right)$. Figure 5 shows the laccase-aided modification of ABTS
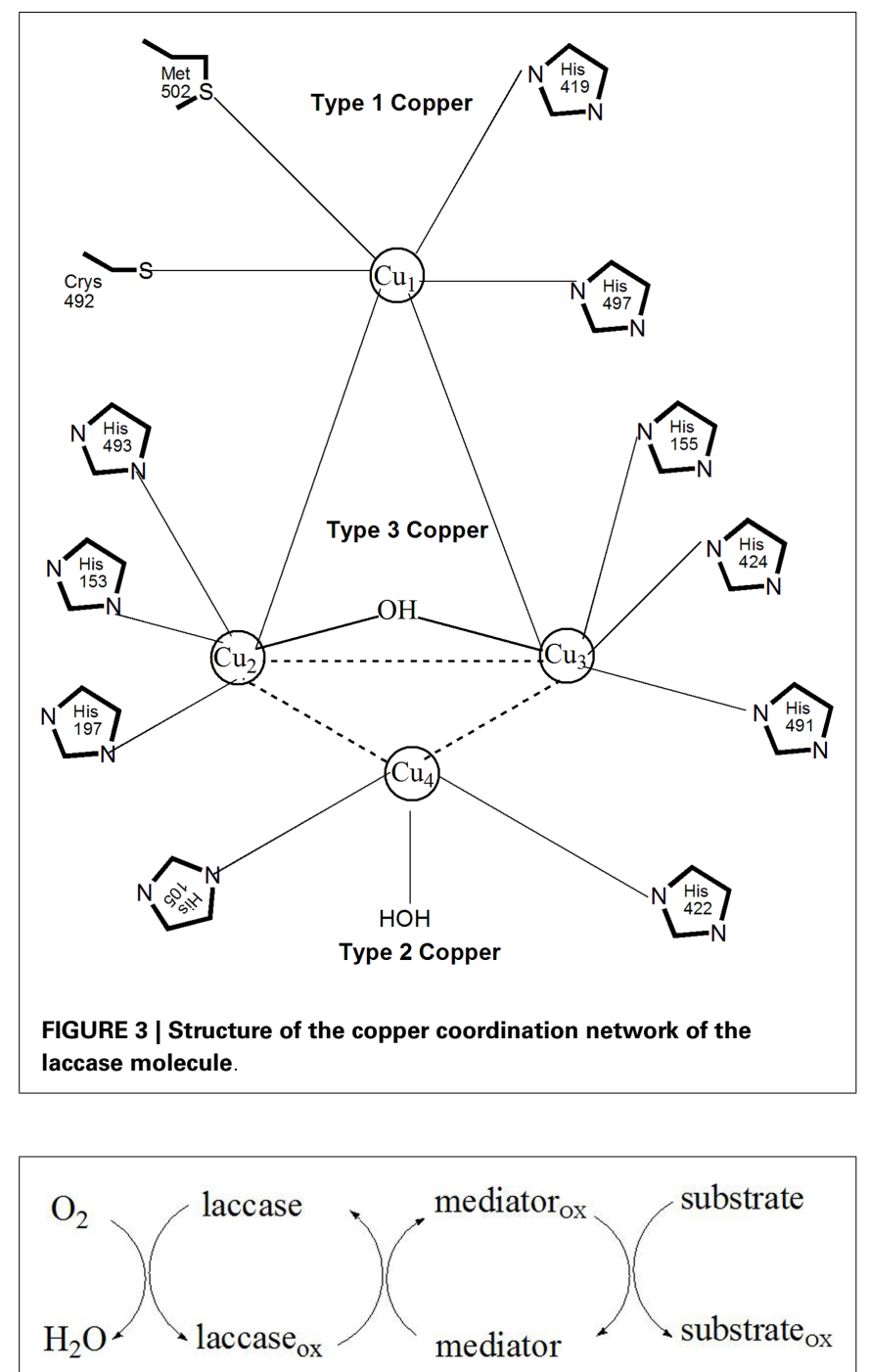

FIGURE 4 | Proposed mechanism of substrate oxidation by LMS.

during oxidization. The redox potential of the semi-oxidized and fully oxidized ABTS was measured as 0.68 and $1.09 \mathrm{~V}$, respectively (Scott et al., 1993). 1-Hydroxybenzotriazole (HBT) was the second laccase mediator that was successfully used in lignin degradation and biobleaching of kraft pulps (Call, 1994). The search for new and efficient LMS has resulted in the chemicals synthesis and evaluation of a number of laccase mediators, including violuric acid (VIO), $N$-hydroxyacetanilide (NHA), $\mathrm{N}$ hydroxyphthalimide (NHI), 2,2,6,6-tetramethylpiperidin-1-yloxy (TEMPO), etc. (Bourbonnais et al., 1997). The structural formulas of some synthetic mediators of the $-\mathrm{N}$-OH-type are displayed in Figure 6(1). A method for selection of effective laccase mediators was proposed (Shleev et al., 2003) consisting of four steps: (1) select compounds that have heterocyclic atoms, $\mathrm{OH}-$, and/or $\mathrm{NH}_{2}$-groups in their structure; (2) test the electrochemical properties of these compounds with and without LMCs; (3) determine the optimum reaction conditions of these compounds during laccase-catalyzed degradation reactions of lignin 


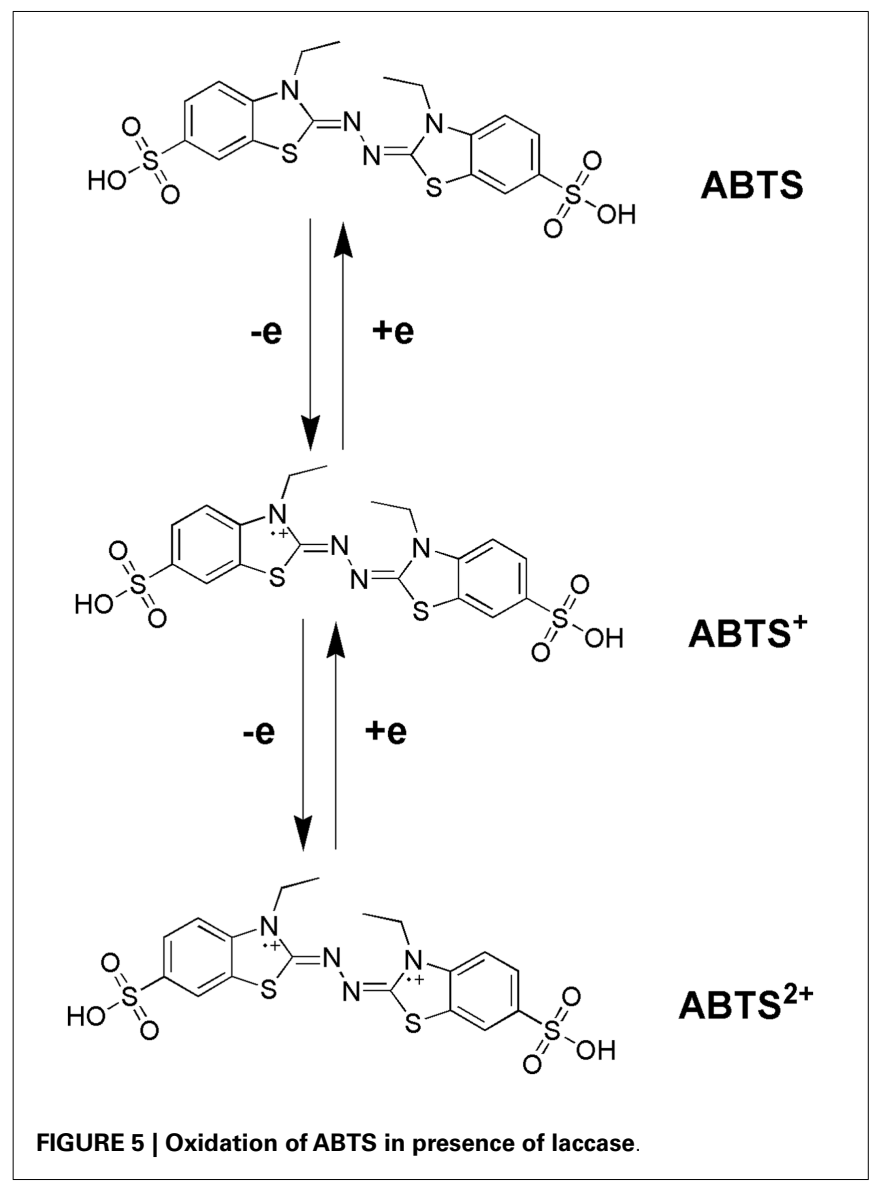

or LMCs; and (4) determine the products of lignin or LMCs degradation by LMS. Using this method, phenothiazine-type mediators have been selected [Figure 6(2)]. In another study, 20 heterocyclic compounds containing $\mathrm{N}$-OH-groups and benzoic acid structures were screened as potential mediators for T. hirsuta laccase (Shumakovich et al., 2006). Derivatives of 1-phenyl-3-methyl pyrazolone were proposed as efficient mediators in LMS oxidation of veratryl alcohol [Figure 6(3)]. The major problems encountered during screening for synthetic mediators are associated with the instability of the mediator intermediates, which resulted in incomplete redox cycles or poor substrate oxidation. In addition, synthetic mediators are expensive, toxic, and difficult to reuse as they form by-products (Srebotnik and Hammel, 2000). Most of them are also inhibitive to laccase at concentrations higher than $1 \mathrm{mM}$. This prompted recent research efforts in search of naturally occurring mediators that may offer environmental and economic advantages.

Phenolic products generated during lignin degradation by white-rot fungi and fungal metabolites were evaluated as potential natural mediators (Eggert et al., 1996). Phenolic compounds have been reported to be able to mediate the oxidation of both nonphenolic part of lignin or non-phenolic model of lignin (Johannes and Majcherczyk, 2000; Astolfi et al., 2005). They can be obtained by extraction from pulp and paper effluents and plant materials at low cost (Camarero et al., 2007). Furthermore, laccases and their natural mediators can be applied in effluent bioremediation and lignocellulosic biorefineries (Cañas and Camarero, 2010). Example of natural phenolic compounds that can serve as laccase mediators in lignin degradation include acetosyringone, syringaldehyde, $p$-coumaric acid, vanillin, acetovanillone (Andreu and Vidal, 2011), 3-hydroxyanthranilic acid (3-HAA) (Eggert et al., 1996, 1997), 4-hydroxybenzoic acid and 4-hydroxybenzylic alcohol (Johannes and Majcherczyk, 2000), hydroquinone (Calcaterra et al., 2008), and phenolsulfonphthalein (d'Acunzo and Galli, 2003). Figure 7 shows the chemical structure of some natural laccase mediators. LMS have gained increased attention in a number of potential applications such as detoxification of industrial effluents, textile dye bleaching, soil bioremediation, manufacture of pharmaceuticals, food and cosmetic products, etc. (Couto and Herrera, 2007). However, the focus of this review is on the potential of LMS to degrade lignin. The mechanism of lignin biodegradation was studied on LMCs, isolated lignins, and fiber-bound wood pulp lignins.

\section{BIODEGRADATION OF LIGNIN WITH LACCASE-MEDIATOR SYSTEMS}

Lignin biodegradation with LMS is an oxidative process of enzyme-catalyzed and mediator-facilitated radical reactions of degradation of both phenolic and non-phenolic aromatic structures in lignin. It has been suggested that the initial oxidative attack is on the phenolic lignin moiety ( $<20 \%$ of total lignin), followed by the destruction of non-phenolic benzylic structures (Camarero et al., 1994). The preferential oxidation of phenolic lignin units results in the release of phenolic residues with oxidized side chains such as phenolic aldehydes, ketones, and acids. These LMW phenolic fragments are then able to penetrate the bulk lignin polymer and act as natural mediators to oxidize more recalcitrant non-phenolic lignin (Reddy et al., 2003). Lignin depolymerization with LMS has been further suggested to proceed by a $\mathrm{C}_{\alpha}-\mathrm{C}_{\beta}$ cleavage of nonphenolic sites in lignin with subsequent solubilization of lignin fragments by formation of hydrophilic lignin-mediator complexes (Srebotnik and Hammel, 2000). Oxidation of non-phenolic LMCs by LMS can follow three different oxidation mechanisms: (1) electron transfer; (2) radical hydrogen atom transfer; and (3) ionic mechanism (Fabbrini et al., 2002). Figure 8 exemplifies the first two oxidation mechanisms. Evidence for the existence of these mechanisms has been provided by examining the product pattern of non-phenolic lignin degradation, and measuring the intra-molecular kinetic isotope effects (Barreca et al., 2004). In the oxidation of non-phenolic LMCs, the efficiency of LMS was reported to be independent of the enzymes properties (Rosado et al., 2012). Oxidation of non-phenolic LMCs by laccase-ABTS was reported to occur via the electron transfer route (Bourbonnais et al., 1998). The laccase-TEMPO acts according to the ionic mechanism, whereas the HBT- and HPI-mediated reactions favor the radical mechanism (Fabbrini et al., 2002). It has been proposed that the HBT radical forms a coupling intermediated product with lignin (Potthast et al., 1997). The intermediate product can subsequently degrade to release the reduced form of benzotriazole (BT), or form a stable complex that binds some of the HBT to lignin via covalent bonding. The laccase-HBT treatment of softwood lignin was reported to result in increased content of $p$-hydroxyphenyl 
1<smiles>On1nnc2ccccc21</smiles><smiles>O=C1c2ccccc2C(=O)N1O</smiles>

n-hydroxyphthalimide<smiles></smiles>

$2,2^{\prime}, 6,6^{\prime}$-tetramethylpiperidine-1-oxyl

2<smiles>c1ccc2c(c1)Nc1ccccc1S2</smiles>

phenothiazine<smiles>O=C(O)CCN1c2ccccc2Sc2ccccc21</smiles>

phenothiazine-10-propionic acid

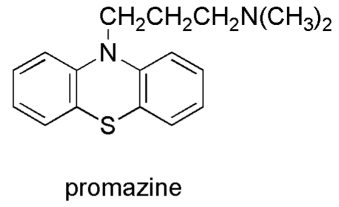

promazine<smiles>Cc1cc(=O)n(-c2cccc(S(=O)(=O)O)c2)[nH]1</smiles>

3 -(3'-sulfophenyl)-3-methyl pyrazolone-5

1-phenyl-2,3-dimethyl amino pyrazolone-5<smiles>Cc1cc(=O)n(-c2ccccc2)[nH]1</smiles>

1-phenyl-3-methyl pyrazolone-5

FIGURE 6 | Chemical structures of some synthetic laccase mediators: (1) >N-OH type; (2) phenothiazine-type; and (3) pyrazolone-type

structures and reduced amount of G-units and aromatic lignin structures (Tamminen et al., 2003). Oxidation with laccase-HBT breaks the $\mathrm{C}_{\alpha}-\mathrm{C}_{\beta}$ link in LMCs such as hydrobenzoin dimers (Xu et al., 1997), and creates carboxylic acid groups in treated pulp lignins (Chakar and Ragauskas, 1999). Figure 9 illustrates the oxidation of non-phenolic $\beta$-O-4-linked LMCs by laccase-HBT results in opening of the aromatic ring ( $\pi$-electron oxidation), oxidation of $C_{\alpha}$, and cleavage of $\beta$-ether and $C_{\alpha}-C_{\beta}$ bonds to generate aromatic carbonyl compounds and carboxylic acids (Kawai et al., $2002)$. In the oxidation reactions, the $\beta$-aryl radical cation or benzylic $\left(C_{\alpha}\right)$ radical intermediates are formed via the electron transfer mechanism. The $\beta$-ether cleavage of the $\beta-O-4$ lignin substructure is caused by reaction with the $\mathrm{C}_{\alpha}$-peroxy radical intermediate produced from the benzylic radical. When T. villosa laccase-HBT was applied in catalytic oxidation of phenolic and non-phenolic LMCs, their nominal molecular weight decreased 5- and 4-times, respectively. Cleavage of the $\mathrm{C}_{\alpha}-\mathrm{C}_{\beta}$ bond occurred in both LMCs thereby about $10 \%$ of their substructures were degraded (Srebotnik and Hammel, 2000). Typical products from lignin degradation with LMS include 2,6-dimethoxy-4-methylbenzaldehyde, 4-ethyl-2,6-dimethoxybenzaldehyde, and 2,6-dimethoxy-4-((E)prop-1-enyl)benzaldehyde (Du et al., 2013). The molecular weight of lignin and its phenolic content are believed to influence the reaction pathways that are catalyzed by laccase and LMS (NikuPaavola et al., 2002). It was suggested that parallel polymerization and depolymerization reactions compete during LMS treatment as phenolic groups in lignin (in particular LMW lignin) may serve as sites for lignin polymerization, which in turn would impede ligninolysis (Srebotnik and Hammel, 2000; Tamminen et al., 2003).

The LMS was first developed as an environmentally friendly bleaching agent for use in the pulp and paper industry (Bourbonnais and Paice, 1990). The system oxidizes and cleaves phenolic and non-phenolic lignin units that become depleted in bleached pulps following chemical bleaching resulting in lower kappa number and higher pulp brightness (Sealey and Ragauskas, 1998; PoppiusLevlin et al., 1999). This process is known as biobleaching and was first introduced as xylanase-aided bleaching of kraft pulps (Viikari et al., 1986). The biobleaching effect with xylanase is due to partial hydrolysis of xylan that is redeposited on the fiber surface during kraft pulping, thereby improving the access of bleaching chemicals residual lignin (Kantelinen et al., 1993). While xylanase assists in lignin removal from pulps indirectly, the LMS attacks lignin directly leading to formation of lower molecular weight oxidized lignin fragments that are susceptible to further degradation and solubilization in alkali (E) during chemical bleaching (Bourbonnais et al., 1997). The LMS-catalyzed lignin degradation and removal from bleached pulps enables the use of less hazardous chlorine-containing bleaching chemicals of environmental concern such as chlorine (C), chlorine dioxide (D), and sodium hypochlorite $(\mathrm{H})$. For instance, biobleaching of industrial pulps with T. hirsuta laccase-HBT increased pulp brightness by up to 
<smiles>Nc1c(O)cccc1C(=O)O</smiles>

3-hydroxyanthranilic acid<smiles>COC1=C(O)C(OC)C(=O)C(CC(C)=O)=C1</smiles>

Acetosyringone<smiles>O=C(O)c1ccc(O)cc1</smiles>

4-hydroxybenzoic acid<smiles>COc1cc(C=O)cc(OC)c1O</smiles>

syringaldehyde<smiles>O=S1(=O)OC(c2ccc(O)cc2)(c2ccc(O)cc2)c2ccccc21</smiles>

phenolsulfonphthalein<smiles>COC(=O)c1cc(OC)c(O)c(OC)c1</smiles><smiles>COc1cc(C=O)ccc1O</smiles>

vanillin

Methyl syringate

FIGURE 7 | Chemical structures of some naturally occurring laccase mediators.

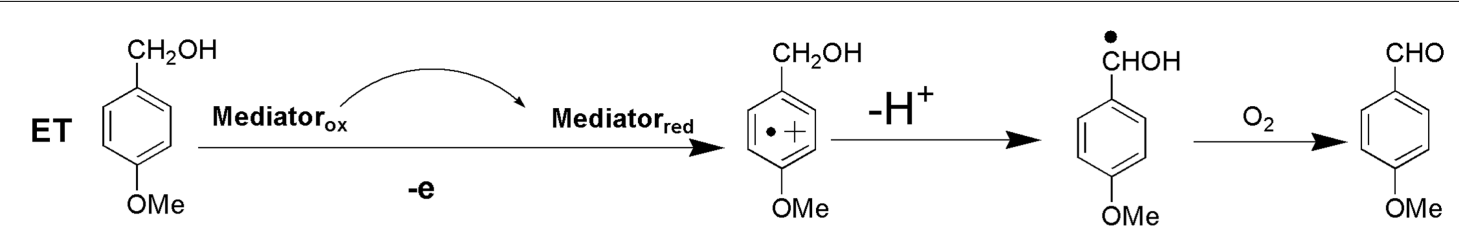

HBT<smiles>COc1ccc(CO)cc1</smiles>

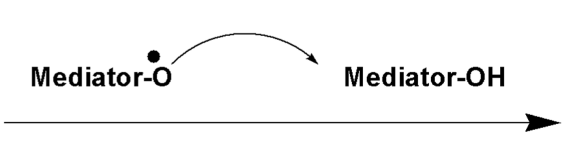<smiles>COc1ccc([C+](C)O)cc1</smiles><smiles>COc1ccc(C=O)cc1C=O</smiles>

FIGURE 8 | Proposed mechanisms of LMS-catalyzed oxidation of 4-methoxybenzyl alcohol (non-phenolic LMC) to 4-methoxybenzaldehyde: (1) electron transfer (ET); (2) hydrogen atom transfer (HAT).

12.2 points in a DED pulp bleaching, alternatively, $40-60 \%$ chlorine dioxide could be used to reach brightness of control pulps (Kandioller and Christov, 2001). In a comparative study, kraft pulp was delignified with several fungal laccases in conjunction with HBT as mediator (Bourbonnais et al., 1997). The most efficient laccase was that of Ganoderma colossum with $40 \%$ lignin 


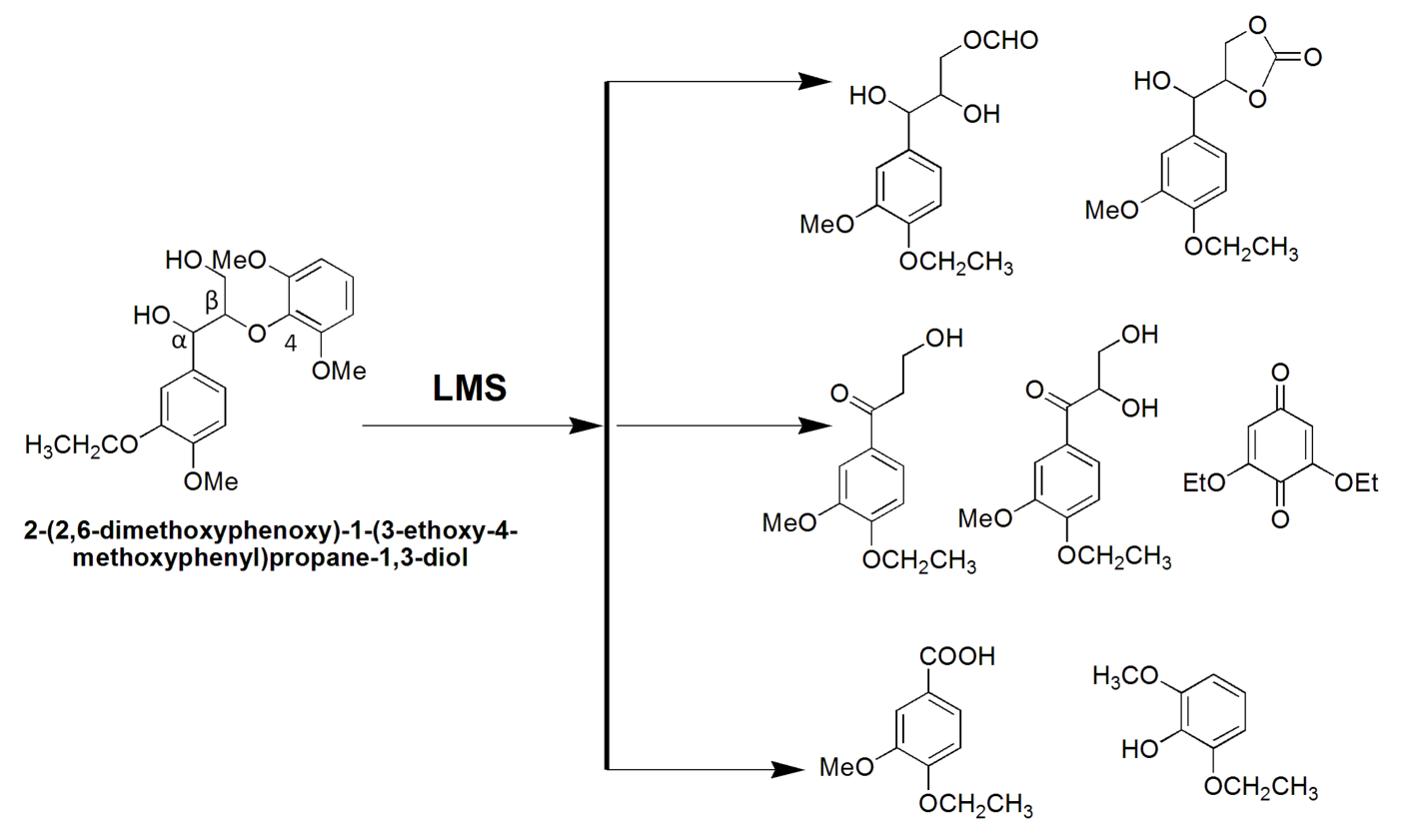

FIGURE 9 | Oxidation of a non-phenolic $\beta-O-4$ LMC by Trametes versicolor laccase-HBT system

removal, followed by T. versicolor laccase $(22 \%)$ and $P$. ostreatus laccase (13\%). The Fusarium proliferatum laccase-ABTS system was able to oxidize and remove $19 \%$ from industrial kraft pine lignin (Indulin AT) predominsntly in the form of ketones $(10 \%)$ and acids (2\%), with significant reduction of G-units and methylated side-chain phenolic compounds in residual lignin (González Arzola et al., 2006). Two LMS, P. cinnabarinus laccaseHBT and Myceliophthora thermophila laccase-methyl syringate, were applied to delignify unbleached eucalyptus kraft pulp (Du et al., 2013). Pyrolysis-GC/MS and NMR analysis revealed that with both systems, $\mathrm{C}_{\alpha}$ in lignin was oxidized whereas the $\mathrm{C}_{\alpha}-$ $\mathrm{C}_{\beta}$ bond and aromatic ring were both cleaved, with accumulation of xylan-lignin fractions containing $S$ and $G$ uncondensed units. Biobleaching of eucalyptus kraft pulps was also studied using bacterial laccases from S. cyaneus (Arias et al., 2003) and Pseudomonas stutzeri (Sharma et al., 2007) with ABTS and HBT as mediators. Due to the high activity, alkali and thermal stability of these enzymes, the LMS proved as efficient lignin degraders (Moya et al., 2011). The extent of pulp delignification with LMS depends on the pulp and mediator type, source of pulp and laccase, and amount of enzyme and mediator used. For instance, pine kraft was delignified 19-40\% depending on the laccase preparation (from several fungal strains) and mediator choice (HBT and ABTS) (Bourbonnais et al., 1997). It has been demonstrated that laccase in combination with HBT is effective on pulps derived from various fiber sources (hardwood, softwood, and bagasse) and produced with different pulping procedures (kraft of sulfite pulping), resulting in delignification up to $60 \%$. In 1997, the first pilot plant trial with laccase-HBT (Lignozym ${ }^{\circledR}$-process) on oxygen-delignified kraft pulps achieved 55\% delignification (Call and Mücke, 1997). However, the LMS is still to be applied on a large scale. Major impediments are the mediator costs and environmental concerns about potential toxic effects of mediators (Ruiz-Dueñas and Martínez, 2009).

\section{CONCLUDING REMARKS}

Lignin presents an abundant component of lignocellulosic biomass, which is currently largely unutilized. It has the potential to replace fossil-based oil as a renewable feedstock for sustainable production of valuable chemicals. The efficient utilization of lignin however requires its depolymerization to LMW phenolics and aromatics that can then serve as the building blocks for chemical syntheses of high-value products. Lignin biodegradation with LMS presents a technological challenge and opportunity that needs further development and optimization.

The ideal laccase should have the following properties: (1) broad substrate specificity; (2) high redox potential; (3) high tolerance to inactivation by radicals, organic solvents, and shearing forces; (4) ability to work with a large number of mediators; (5) broad $\mathrm{pH}$ and temperature optima; (6) high enzyme activity and stability; and (7) low production costs. Unfortunately, there is no "universal" laccase that fulfills all above criteria at present, although novel enzymes with improved properties have been obtained. Strategies for further improvements of laccase may include generic engineering and cloning in suitable heterologous hosts for enzyme overproduction, protein engineering to enhance enzyme kinetics and substrate binding, and directed evolution to improve enzyme activity and stability, etc. One of the main targets for improvements is the type 1 copper site, which defines the redox potential of laccases. Modifications in the amino acid composition in the enzyme active site of $T$. versicolor laccase improved enzyme activity and affinity toward larger phenolic substrates (Galli et al., 2011). Substitution of the aromatic amino acids residues with non-aromatic resulted in increased resistance to inactivation by 
free radicals (Li et al., 1999). Directed evolution was recently used to: (1) increase laccase activity 170 - to 32,000 -fold and improve its $\mathrm{pH}$ and temperature stability (Bulter et al., 2003; Maté et al., 2010); (2) increase the tolerance of laccase to ethanol and acetonitrile by 30 and 20\%, respectively (Alcalde et al., 2005). Recent advancements in non-aqueous enzymology allows improved performance of solvent-tolerant laccases in lignin biodegradation due to the better accessibility to lignin in organic solvents such as dimethyl sulfoxide, cetyltrimethylammonium bromide, ionic liquids, etc. (Weihua and Hongzhang, 2008; Rehmann et al., 2014). In addition, development of effective laccase immobilization systems will decrease the cost of operations and create a more sustainable process (Couto and Herrera, 2007).

Challenges that need to be overcome in the development of laccase mediators include: (1) reduced production costs; (2) use of natural, non-toxic mediators present in vitro in lignocellulosic biomass; (3) improved recyclability; (4) high redox potential and ability to effectively oxidize both phenolic and non-phenolic lignin structures; (5) stability of mediator intermediates; (6) lack of mediator side-reactions and consumption in by-products; (7) no inhibitory effect on laccases; (8) ability to form highly efficient LMS with more than one laccase. Nowadays, the central role that LMS can play in lignin biodegradation at the future lignocellulosic biorefineries is increasingly recognized. The potential of LMS to remove lignin from plant biomass could be exploited as an enzymatic pretreatment method in cellulosic ethanol production. This would prevent the formation of inhibitory compounds such as furfural and phenols, which are typically generated during thermochemical pretreatment, and facilitate the enzymatic hydrolysis and fermentation steps of biomass conversion to bioethanol (Jurado et al., 2009).

\section{ACKNOWLEDGMENTS}

This material is based upon work supported by the National Science Foundation EPSCoR Cooperative Agreement \#IIA-1330842. Technical support by the Center for Bioprocessing Research \& Development (CBRD) at the South Dakota School of Mines \& Technology (SDSM\&T) is gratefully acknowledged.

\section{REFERENCES}

Adler, E. (1977). Lignin chemistry - past, present and future. Wood Sci. Technol. 11, 169-218. doi:10.1007/BF00365615

Alcalde, M., Bulter, T., Zumárraga, M., Garcia-Arellano, H., Mencia, M., Plou, F. J., et al. (2005). Screening mutant libraries of fungal laccases in the presence of organic solvents. J. Biomol. Screen. 10, 624-631. doi:10.1177/1087057105277058

Andreu, G., and Vidal, T. (2011). Effects of laccase-natural mediator systems on kenaf pulp. Bioresour. Technol. 102, 5932-5937. doi:10.1016/j.biortech.2011.03.008

Arias, M. E., Arenas, M., Rodríguez, J., Soliveri, J., Ball, A. S., and Hernández, M. (2003). Kraft pulp biobleaching and mediated oxidation of a nonphenolic substrate by laccase from Streptomyces cyaneus CECT 3335. Appl. Environ. Microbiol. 69, 1953-1958. doi:10.1128/AEM.69.4.1953-1958.2003

Astolfi, P., Brandi, P., Galli, C., Gentili, P., Gerini, M. F., Greci, L., et al. (2005). New mediators for the enzyme laccase: mechanistic features and selectivity in the oxidation of non-phenolic substrates. New J. Chem. 29, 1308-1317. doi:10.1039/b507657a

Bailey, M. R., Woodard, S. L., Callaway, E., Beifuss, K., Magallanes-Lundback, M., Lane, J. R., et al. (2004). Improved recovery of active recombinant laccase from maize seed. Appl. Microbiol. Biotechnol. 63, 390-397. doi:10.1007/s00253-003$1362-\mathrm{z}$
Balakshin, M. Y., Capanema, E. A., and Chang, H.-M. (2009). "Recent advances in the isolation and analysis of lignins and lignin-carbohydrate complexes," in Characterization of Lignocellulosic Materials, ed. T. Q. Hu (Oxford: Blackwell Publishing Ltd.), 148-170.

Baldrian, P. (2006). Fungal laccases - occurrence and properties. FEMS Microbiol. Rev. 30, 215-242. doi:10.1111/j.1574-4976.2005.00010.x

Barreca, A. M., Sjögren, B., Fabbrini, M., Galli, C., and Gentili, P. (2004). Catalytic efficiency of some mediators in laccase-catalyzed alcohol oxidation. Biocatal. Biotransform. 22, 105-112. doi:10.1080/10242420410001692750

Berdy, J. (2005). Bioactive microbial metabolites. J. Antibiot. (Tokyo) 58, 1-26. doi:10.1038/ja.2005.1

Blanquez, P., Casas, N., Font, X., Gabarrell, X., Sarra, M., Caminal, G., et al. (2004). Mechanism of textile metal dye biotransformation by Trametes versicolor. Water Res. 38, 2166-2172. doi:10.1016/j.watres.2004.01.019

Bourbonnais, R., Leech, D., and Paice, M. G. (1998). Electrochemical analysis of the interactions of laccase mediators with lignin model compounds. Biochim. Biophys. Acta 1379, 381-390. doi:10.1016/S0304-4165(97)00117-7

Bourbonnais, R., and Paice, M. G. (1990). Oxidation of non-phenolic substrates: an expanded role for laccase in lignin biodegradation. FEBS Lett. 267, 99-102. doi:10.1016/0014-5793(90)80298-W

Bourbonnais, R., Paice, M. G., Freiermuth, B., Bodie, E., and Borneman, S. (1997). Reactivities of various mediators and laccases with kraft pulp and lignin model compounds. Appl. Environ. Microbiol. 63, 4627-4632.

Bourbonnais, R., Paice, M. G., Reid, I. D., Lanthier, P., and Yaguchi, M. (1995). Lignin oxidation by laccase isozymes from Trametes versicolor and role of the mediator 2,2'-azinobis(3-ethylbenzthiazoline-6-sulfonate) in kraft lignin depolymerization. Appl. Environ. Microbiol. 61, 1876-1880.

Bozell, J. J., Holladay, J. E., Johnson, D., and White, J. F. (2007). Top Value Added Candidates from Biomass, Volume II: Results of Screening for Potential Candidates from Biorefinery Lignin. Richland, WA: Pacific Northwest National Laboratory.

Brunow, G. (2001). "Methods to reveal the structure of lignin," in Lignin, Humic Substances and Coal, Vol. 1, eds M. Hofrichter and A. Steinbuchel (Weinheim: Wiley-VCH), 89-118.

Bulter, T., Alcalde, M., Sieber, V., Meinhold, P., Schlachtbauer, C., and Arnold, F. H. (2003). Functional expression of a fungal laccase in Saccharomyces cerevisiae by directed evolution. Appl. Environ. Microbiol. 69, 987-995. doi:10.1128/AEM.69. 8.5037.2003

Calcaterra, A., Galli, C., and Gentili, P. (2008). Phenolic compounds as likely natural mediators of laccase: a mechanistic assessment. J. Mol. Catal. B Enzym. 51, 118-120. doi:10.1016/j.molcatb.2007.11.023

Call, H. P., and Mücke, I. (1997). History, overview and applications of mediated lignolytic systems, especially laccase-mediator-systems (Lignozym ${ }^{\circledR}$-process). J. Biotechnol. 53, 163-202. doi:10.1016/S0168-1656(97)01683-0

Call, H. P. (1994). Process for modifying, breaking down or bleaching lignin materials containing lignin or like substances. World Patent Application WO 94/29510.

Camarero, S., Galletti, G. C., and Martínez, A. T. (1994). Preferential degradation of phenolic lignin units by two white rot fungi. Appl. Environ. Microbiol. 60, 4509-4516.

Camarero, S., Gutiérrez Suárez, A., Ibarra, D., Martínez Ferrer, Á. T., Molina, S., Rencoret, J., et al. (2007). Removal of lipophilic extractives from paper pulp by laccase and lignin-derived phenols as natural mediators. Environ. Sci. Technol. 41, 4124-4129. doi:10.1021/es062723+

Cañas, A. I., and Camarero, S. (2010). Laccases and their natural mediators: biotechnological tools for sustainable eco-friendly processes. Biotechnol. Adv. 28, 694-705. doi:10.1016/j.biotechadv.2010.05.002

Capanema, E. A., Balakshin, M. Y., and Kadla, J. F. (2004). A comprehensive approach for quantitative lignin characterization by NMR spectroscopy. J. Agric. Food Chem. 52, 1850-1860. doi:10.1021/jf035282b

Chakar, F. S., and Ragauskas, A. J. (1999). "Fundamental investigation of laccase mediator delignification on high lignin content kraft pulps," in Proceedings of the 10th International Symposium on Wood and Pulping Chemistry, Vol. 1 (Yokohama, Japan), 566-570.

Chefetz, B., Chen, Y., and Hadar, Y. (1998). Purification and characterization of laccase from Chaetomium thermophilium and its role in humification. Appl. Environ. Microbiol. 64, 3175-3179.

Claus, H. (2003). Laccases and their occurrence in prokaryotes. Arch. Microbiol. 179, 145-150. doi:10.1007/s00203-002-0510-7 
Couto, S., and Herrera, J. (2007). Industrial and biotechnological applications of laccases: a review. Biotechnol. Adv. 24, 500-513. doi:10.1016/j.biotechadv.2006. 04.003

d'Acunzo, F., and Galli, C. (2003). First evidence of catalytic mediation by phenolic compounds in the laccase-induced oxidation of lignin models. Eur. J. Biochem. 270, 3634-3640. doi:10.1046/j.1432-1033.2003.03752.x

d'Acunzo, F., Galli, C., and Masci, B. (2002). Oxidation of phenols by laccase and laccase-mediator systems. Eur. J. Biochem. 269, 5330-5335. doi:10.1046/j.14321033.2002.03256.x

del Pilar Castillo, M., Ander, P., and Stenstrom, J. (1997). Lignin and manganese peroxidase activity in extracts from straw solid substrate fermentations. Biotechnol. Tech. 11, 701-706. doi:10.1023/A:1018423829918

Dhakar, K., and Pandey, A. (2013). Laccase production from a temperature and $\mathrm{pH}$ tolerant fungal strain of Trametes hirsuta (MTCC 11397). Enzyme Res. 2013, 9. doi: $10.1155 / 2013 / 869062$

Du, X., Li, J., Gellerstedt, G., Rencoret, J., Del Río, J. C., Martínez, A. T., et al. (2013). Understanding pulp delignification by laccase-mediator systems through isolation and characterization of lignin-carbohydrate complexes. Biomacromolecules 14, 3073-3080. doi:10.1021/bm4006936

Dwivedi, U. N., Singh, P., Pandey, V. P., and Kumar, A. (2011). Structure-function relationship among bacterial, fungal and plant laccases. J. Mol. Catal. B Enzym. 68, 117-128. doi:10.1016/j.molcatb.2010.11.002

Eggert, C., Temp, U., Dean, J. F., and Eriksson, K.-E. (1996). A fungal metabolite mediates degradation of non-phenolic lignin structures and synthetic lignin by laccase. FEBS Lett. 391, 144-148. doi:10.1016/0014-5793(96)00719-3

Eggert, C., Temp, U., and Eriksson, K.-E. (1997). Laccase is essential for lignin degradation by the white-rot fungus Pycnoporus cinnabarinus. FEBS Lett. 407, 89-92. doi:10.1016/S0014-5793(97)00301-3

Fabbrini, M., Galli, C., and Gentili, P. (2002). Comparing the catalytic efficiency of some mediators of laccase. J. Mol. Catal. B Enzym. 16, 231-240. doi:10.1016/S1381-1177(01)00067-4

Faravelli, T., Frassoldati, A., Migliavacca, G., and Ranzi, E. (2010). Detailed kinetic modeling of the thermal degradation of lignins. Biomass Bioenergy 34, 290-301. doi:10.1016/j.biombioe.2009.10.018

Freudenberg, K. (1959). Biosynthesis and constitution of lignin. Nature 183, 1152-1155. doi:10.1038/1831152a0

Freudenberg, K. (1962). Biogenesis and constitution of lignin. Pure Appl. Chem. 5, 9-20. doi:10.1351/pac196205010009

Freudenberg, K. (1965). Lignin: its constitution and formation from $p$ hydroxycinnamyl alcohols: lignin is duplicated by dehydrogenation of these alcohols; intermediates explain formation and structure. Science 148, 595-600. doi:10.1126/science.148.3670.595

Freudenberg, K., and Hübner, H. H. (1952). Oxyzimtalkohole und ihre Dehydrierungs-polymerisate. Chem. Ber. 85, 1181-1191. doi:10.1002/cber. 19520851213

Freudenberg, K., and Neish, A. C. (1968). Molecular biology, biochemistry and biophysics. In Constitution and Biosynthesis of Lignin, eds G. F. Springer and A. Kleinzeller (New York: Springer-Verlag), 129. doi:10.1126/science.165.3895.784

Galbe, M., and Zacchi, G. (2007). Pretreatment of lignocellulosic materials for efficient bioethanol production. Adv. Biochem. Eng. Biotechnol. 108, 41-65. doi:10.1007/10_2007_070

Galli, C., Gentilli, P., Jolivalt, C., Madzak, C., and Vadalà, R. (2011). How is the reactivity of laccase affected by single-point mutations? Engineering laccase for improved activity towards sterically demanding substrates. Appl. Microbiol. Biotechnol. 91, 123-131. doi:10.1007/s00253-011-3240-4

Gianfreda, L., Xu, F., and Bollag, J.-M. (1999). Laccases: a useful group of oxidoreductive enzymes. Biorem. J. 3, 1-25. doi:10.1080/10889869991219163

Givaudan, A., Effosse, A., Faure, D., Potier, P., Bouillant, M.-L., and Bally, R. (1993). Polyphenol oxidase in Azospirillum lipoferum isolated from rice rhizosphere: evidence for laccase activity in non-motile strains of Azospirillum lipoferum. FEMS Microbiol. Lett. 108, 205-210. doi:10.1111/j.1574-6968.1993.tb06100.x

González Arzola, K., Polvillo, O., Arias, M. E., Perestelo, F., Carnicero, A., GonzálezVila, F. J., et al. (2006). Early attack and subsequent changes produced in an industrial lignin by a fungal laccase and a laccase-mediator system: an analytical approach. Appl. Microbiol. Biotechnol. 73, 141-150. doi:10.1007/s00253-0060630-0

Gosselink, R. J., De Jong, E., Guran, B., and Abächerli, A. (2004). Co-ordination network for lignin - standardisation, production and applications adapted to market requirements (EUROLIGNIN). Ind. Crops Prod. 20, 121-129. doi:10. 1016/j.indcrop.2004.04.015

Grove, S. N., and Bracker, C. E. (1970). Protoplasmic organization of hyphal tips among fungi: vesicles and spitzenkörper. J. Bacteriol. 104, 989-1009.

Gutiérrez, A., Del Río, J. C., Ibarra, D., Rencoret, J., Romero, J., Speranza, M., et al. (2006). Enzymatic removal of free and conjugated sterols forming pitch deposits in environmentally sound bleaching of eucalypt paper pulp. Environ. Sci. Technol. 40, 3416-3422. doi:10.1021/es052547p

Hatakka, A. (1994). Lignin-modifying enzymes from selected white-rot fungi: production and role from in lignin degradation. FEMS Microbiol. Rev. 13, 125-135. doi:10.1111/j.1574-6976.1994.tb00039.x

He, S.-H., and Li, H.-J. (2013). Amylostereum orientale sp. nov. (Basidiomycota, Russulales) and first report of A. areolatum in China based on morphological and molecular characters. Nord. J. Bot. 31, 728-733. doi:10.1111/j.1756-1051.2013. 01756.x

Higuchi, T. (2004). Microbial degradation of lignin: role of lignin peroxidase, manganese peroxidase, and laccase. Proc. Jpn. Acad. Ser. B 80, 204-214. doi:10.1016/ j.chemosphere.2011.05.021

Hildén, K., Hakala, T., and Lundell, T. (2009). Thermotolerant and thermostable laccases. Biotechnol. Lett. 31, 1117-1128. doi:10.1007/s10529-009-9998-0

Hildén, K., Hakala, T., Maijala, P., Lundell, T., and Hatakka, A. (2007). Novel thermotolerant laccases produced by the white-rot fungus Physisporinus rivulosus. Appl. Microbiol. Biotechnol. 77, 301-309. doi:10.1007/s00253-0071155-X

Hood, E. E., Bailey, M. R., Beifuss, K., Magallanes-Lundback, M., Horn, M. E., Callaway, E., et al. (2003). Criteria for high-level expression of a fungal laccase gene in transgenic maize. Plant Biotechnol. J. 1, 129-140. doi:10.1046/j.1467-7652. 2003.00014.x

Hoopes, J. T., and Dean, J. F. (2004). Ferroxidase activity in a laccase-like multicopper oxidase from Liriodendron tulipifera. Plant. Physiol. Biochem. 42, 27-33. doi:10.1016/j.plaphy.2003.10.011

Jiao, R. H., Xu, S., Liu, J. Y., Ge, H. M., Ding, H., Xu, C., et al. (2006). Chaetominine, a cytotoxic alkaloid produced by endophytic Chaetomium sp. IFB-E015. Org. Lett. 8, 5709-5712. doi:10.1021/ol062257t

Johannes, C., and Majcherczyk, A. (2000). Natural mediators in the oxidation of polycyclic aromatic hydrocarbons by laccase mediator systems. Appl. Environ. Microbiol. 66, 524-528. doi:10.1128/AEM.66.2.524-528.2000

Jurado, M., Prieto, A., Martinez-Alcala, A., Martinez, A. T., and Martinez, M. J. (2009). Laccase detoxification of steam-exploded wheat straw for second generation bioethanol. Bioresour. Technol. 100, 6378-6384. doi:10.1016/j.biortech. 2009.07.049

Kandioller, G., and Christov, L. (2001). "Evaluation of the delignification and bleaching abilities of selected laccases with HBT on different pulps," in Oxidative Delignification Chemistry, ed. D. S. Argyropoulos (Washington, DC: American Chemical Society), 427-443.

Kang, S., Xiao, L., Meng, L., Zhang, X., and Sun, R. (2012). Isolation and structural characterization of lignin from cotton stalk treated in an ammonia hydrothermal system. Int. J. Mol. Sci. 13, 15209-15226. doi:10.3390/ijms131115209

Kantelinen, A., Hortling, B., Sundquist, J., Linko, M., and Viikari, L. (1993). Proposed mechanism of the enzymatic bleaching of kraft pulp with xylanases. Holzforschung 47, 318-324. doi:10.1515/hfsg.1993.47.4.318

Karhunen, P., Rummakko, P., Sipilä, J., Brunow, G., and Kilpeläinen, I. (1995). The formation of dibenzodioxocin structures by oxidative coupling. A model reaction for lignin biosynthesis. Tetrahedron Lett. 36, 4501-4504. doi:10.1016/00404039(95)00769-9

Kawai, S., Asukai, M., Ohya, N., Okita, K., Ito, T., and Ohashi, H. (1999). Degradation of a non-phenolic $\beta-O-4$ substructure and of polymeric lignin model compounds by laccase of Coriolus versicolor in the presence of 1 hydroxybenzotriazole. FEMS Microbiol. Lett. 170, 51-57. doi:10.1111/j.15746968.1999.tb13354.x

Kawai, S., Nakagawa, M., and Ohashi, H. (2002). Degradation mechanisms of a nonphenolic $\beta-\mathrm{O}-4$ lignin model dimer by Trametes versicolor laccase in the presence of 1-hydroxybenzotriazole. Enzyme Microb. Technol. 30, 482-489. doi:10.1016/S0141-0229(01)00523-3

Kiiskinen, L.-L., Kruus, K., Bailey, M., Ylösmäki, E., Siika-Aho, M., and Saloheimo, M. (2004). Expression of Melanocarpus albomyces laccase in Trichoderma reesei and characterization of the purified enzyme. Microbiology 150, 3065-3074. doi:10.1099/mic.0.27147-0 
Kim, H., Hahn, M., Grabowski, P., Mcpherson, D. C., Otte, M. M., Wang, R., et al. (2006). The Bacillus subtilis spore coat protein interaction network. Mol. Microbiol. 59, 487-502. doi:10.1111/j.1365-2958.2005.04968.x

LaFayette, P., Eriksson, K.-E., and Dean, J. D. (1999). Characterization and heterologous expression of laccase cDNAs from xylem tissues of yellow-poplar (Liriodendron tulipifera). Plant Mol. Biol. 40, 23-35. doi:10.1023/A:1026437406859

Lee, I.-Y., Jung, K.-H., Lee, C.-H., and Park, Y.-H. (1999). Enhanced production of laccase in Trametes vesicolor by the addition of ethanol. Biotechnol. Lett. 21, 965-968. doi:10.1007/s11274-013-1420-3

Leigh, S. D. (1997). Alkaline serine protease Streptomyces griseus var. alkaliphus having enhanced stability against urea or guanidine. Official Gazette U.S. Pat. \& Trademark Office Pat. 1200(2): 1254, Y 8.

Li, K., Xu, F., and Eriksson, K.-E. (1999). Comparison of fungal laccases and redox mediators in oxidation of a nonphenolic lignin model compound. Appl. Environ. Microbiol. 65, 2654-2660.

Macfarlane, A. L., Prestidge, R., Farid, M. M., and Chen, J. J. (2009). Dissolved air flotation: a novel approach to recovery of organosolv lignin. Chem. Eng. J. 148, 15-19. doi:10.1016/j.cej.2008.07.036

Mansur, M., Arias, M. E., Copa-Patiño, J. L., Flärdh, M., and González, A. E. (2003). The white-rot fungus Pleurotus ostreatus secretes laccase isozymes with different substrate specificities. Mycologia 95, 1013-1020. doi:10.2307/3761909

Margot, J., Bennati-Granier, C., Maillard, J., Blanquez, P., Barry, D., and Holliger, C. (2013). Bacterial versus fungal laccase: potential for micropollutant degradation. AMB Express 3, 63. doi:10.1186/2191-0855-3-63

Martins, L. G., Soares, C. M., Pereira, M. M., Teixeira, M., Costa, T., Jones, G. H., et al. (2002). Molecular and biochemical characterization of a highly stable bacterial laccase that occurs as a structural component of the Bacillus subtilis endospore coat. J. Biol. Chem. 277, 18849-18859. doi:10.1074/jbc.M200827200

Maté, D., García-Burgos, C., García-Ruiz, E., Ballesteros, A. O., Camarero, S., and Alcalde, M. (2010). Laboratory evolution of high-redox potential laccases. Chem. Biol. 17, 1030-1041. doi:10.1016/j.chembiol.2010.07.010

Mazumder, S., Basu, S. K., and Mukherjee, M. (2009). Laccase production in solidstate and submerged fermentation by Pleurotus ostreatus. Eng. Life Sci. 9, 45-52. doi:10.1002/elsc.200700039

McMahon, A. M., Doyle, E. M., Brooks, S., and O'Connor, K. E. (2007). Biochemical characterisation of the coexisting tyrosinase and laccase in the soil bacterium Pseudomonas putida F6. Enzyme Microb. Technol. 40, 1435-1441. doi:10.1016/j.enzmictec.2006.10.020

Medhavi, V., and Lele, S. (2009). Laccase: properties and applications. Bioresources $4,1694-1717$.

Messerschmidt, A., and Huber, R. (1990). The blue oxidases, ascorbate oxidase, laccase and ceruloplasmin modelling and structural relationships. Eur. J. Biochem. 187, 341-352. doi:10.1111/j.1432-1033.1990.tb15311.x

Mikolasch, A., and Schauer, F. (2009). Fungal laccases as tools for the synthesis of new hybrid molecules and biomaterials. Appl. Microbiol. Biotechnol. 82, 605-624. doi:10.1007/s00253-009-1869-z

Morozova, O. V., Shumakovich, G. P., Gorbacheva, M. A., Shleev, S. V., and Yaropolov, A. I. (2007a). "Blue” laccases. Biochemistry 72, 1136-1150. doi:10. 1134/S0006297907100112

Morozova, O. V., Shumakovich, G. P., Shleev, S. V., and Yaropolov, Y. I. (2007b). Laccase-mediator systems and their applications: a review. Appl. Biochem. Biotechnol. 43, 523-535. doi:10.1134/S0003683807050055

Moya, R., Saastamoinen, P., Hernández, M., Suurnäkki, A., Arias, E., and Mattinen, M.-L. (2011). Reactivity of bacterial and fungal laccases with lignin under alkaline conditions. Bioresour. Technol. 102, 10006-10012. doi:10.1016/j.biortech. 2011.08.046

Nandan, A. S., and Nampoothiri, K. M. (2014). Unveiling aminopeptidase P from Streptomyces lavendulae: molecular cloning, expression and biochemical characterization. Enzyme Microb. Technol. 55, 7-13. doi:10.1016/j.enzmictec. 2013.11.003

Niku-Paavola, M.-L., Tamminen, T., Hortling, B., Viikari, L., and Poppius-Levlin, K. (2002). "Reactivity of high and low molar mass lignin in the laccase catalysed oxidation," in Biotechnology in the Pulp and Paper Industry, Vol. 21, eds L. Viikari and R. Lantto (Amsterdam: Elsevier), 121-130.

Palmieri, G., Cennamo, G., Faraco, V., Amoresano, A., Sannia, G., and Giardina, P. (2003). Atypical laccase isoenzymes from copper supplemented Pleurotus ostreatus cultures. Enzyme Microb. Technol. 33, 220-230. doi:10.1016/S0141-0229(03) 00117-0
Palmieri, G., Giardina, P., Bianco, C., Fontanella, B., and Sannia, G. (2000). Copper induction of laccase isoenzymes in the ligninolytic fungus Pleurotus ostreatus. Appl. Environ. Microbiol. 66, 920-924. doi:10.1128/AEM.66.3.920-924.2000

Pandey, A., Szakacs, G., Soccol, C. R., Rodriguez-Leon, J. A., and Soccol, V. T. (2001). Production, purification and properties of microbial phytases. Bioresour. Technol. 77, 203-214. doi:10.1016/S0960-8524(00)00139-5

Perlack, R. D., Wright, L. L., Turholow, A. F., Graham, R. L., Stokes, B. J., and Erbah, D. C. (2005). Biomass as Feedstock for a Bioenergy and Bioproducts Industry: The Technical Feasibility of a Billion-Ton Annual Supply. Oka Ridge: U.S. Department of Energy.

Pezzella, C., Lettera, V., Piscitelli, A., Giardina, P., and Sannia, G. (2013). Transcriptional analysis of Pleurotus ostreatus laccase genes. Appl. Microbiol. Biotechnol. 97, 705-717. doi:10.1007/s00253-012-3980-9

Phelan, R., Barret, M., Cotter, P., Connor, P., Chen, R., Morrissey, J., et al. (2013). Subtilomycin: a new lantibiotic from Bacillus subtilis strain MMA7 Isolated from the marine sponge Haliclona simulans. Mar. Drugs 11, 1878-1898. doi:10.3390/ md11061878

Piontek, K., Antorini, M., and Choinowski, T. (2002). Crystal structure of a laccase from the fungus Trametes versicolor at 1.90-Å resolution containing a full complement of coppers. J. Biol. Chem. 277, 37663-37669. doi:10.1074/jbc.M204571200

Poppius-Levlin, K., Wang, M., Tamminen, T., Hortling, B., Viikari, L., and NikuPaavola, M. L. (1999). Effects of laccase/HBT treatment on pulp and lignin structures. J. Pulp Paper Sci. 25, 90-94.

Potthast, A., Koch, H., and Fischer, K. (1997). "The laccase-mediator system - reaction with model compounds and pulp," in Preprints 9th Intl. Symp. Wood Pulp (Montreal, Canada), S. F1-4-F1-8. Chem. Tech. Section F2-1-F2-4.

Reddy, L., Odhav, B., and Bhoola, K. D. (2003). Natural products for cancer prevention: a global perspective. Pharmacol. Ther. 99, 1-13. doi:10.1016/S01637258(03)00042-1

Rehmann, L., Ivanova, E., Gunaratne, H. Q., Seddon, K. R., and Stephens, G. (2014). Enhanced laccase stability through mediator partitioning into hydrophobic ionic liquids. Green Chem. 16, 1462-1469. doi:10.1039/c3gc42189a

Reinhammar, B. R., and Vänngåd, T. I. (1971). The electron-accepting sites in Rhus vernicifera lacase as studied by anaerobic oxidation-reduction titrations. Eur. J. Biochem. 18, 463-468. doi:10.1111/j.1432-1033.1971.tb01264.x

Rosado, T., Bernardo, P., Koci, K., Coelho, A. V., Robalo, M. P., and Martins, L. O. (2012). Methyl syringate: an efficient phenolic mediator for bacterial and fungal laccases. Bioresour. Technol. 124, 371-378. doi:10.1016/j.biortech.2012.08.023

Rosconi, F., Fraguas, L. F., Martínez-Drets, G., and Castro-Sowinski, S. (2005). Purification and characterization of a periplasmic laccase produced by Sinorhizobium meliloti. Enzyme Microb. Technol. 36, 800-807. doi:10.1016/j.enzmictec. 2005.01.003

Ruiz-Dueñas, F. J., and Martínez, Á. T. (2009). Microbial degradation of lignin: how a bulky recalcitrant polymer is efficiently recycled in nature and how we can take advantage of this. Microb. Biotechnol. 2, 164-177. doi:10.1111/j.1751-7915.2008. 00078.x

Salkinoja-Salonen, M. S., Vuorio, R., Andersson, M. A., Kämpfer, P., Andersson, M. C., Honkanen-Buzalski, T., et al. (1999). Toxigenic strains of Bacillus licheniformis related to food poisoning. Appl. Environ. Microbiol. 65, 4637-4645.

Saraiva, J., Tavares, A. M., and Xavier, A. R. (2012). Effect of the inducers veratryl alcohol, xylidine, and ligninosulphonates on activity and thermal stability and inactivation kinetics of laccase from Trametes versicolor. Appl. Biochem. Biotechnol. 167, 685-693. doi:10.1007/s12010-012-9719-3

Schmidt, O. (2007). Indoor wood-decay basidiomycetes: damage, causal fungi, physiology, identification and characterization, prevention and control. Mycol. Prog. 6, 261-279. doi:10.1007/s11557-007-0534-0

Schneider, P., Caspersen, M. B., Mondorf, K., Halkier, T., Skov, L. K., Østergaard, P. R., et al. (1999). Characterization of a Coprinus cinereus laccase. Enzyme Microb. Technol. 25, 502-508. doi:10.1016/S0141-0229(99)00085-X

Scott, S. L., Chen, W. J., Bakac, A., and Espenson, J. H. (1993). Spectroscopic parameters, electrode potentials, acid ionization constants, and electron exchange rates of the 2,2'-azinobis(3-ethylbenzothiazoline-6-sulfonate) radicals and ions. J. Phys. Chem. 97, 6710-6714. doi:10.1021/j100127a022

Sealey, J., and Ragauskas, A. J. (1998). Investigation of laccase/Nhydroxybenzotriazole delignification of kraft pulp. J. Wood Chem. Technol. 18, 403-416. doi:10.1080/02773819809349588

Sharma, P., Goel, R., and Capalash, N. (2007). Bacterial laccases. World J. Microbiol. Biotechnol. 23, 823-832. doi:10.1007/s11274-006-9305-3 
Shleev, S. V., Khan, I. G., Gazaryan, I. G., Morozova, O. V., and Yaropolov, A. I. (2003). Novel laccase redox mediators. Appl. Biochem. Biotechnol. 111, 167-183. doi:10.1385/ABAB:111:3:167

Shleev, S. V., Morozova, O. V., Nikitina, O. V., Gorshina, E. S., Rusinova, T. V., Serezhenkov, V. A., et al. (2004). Comparison of physico-chemical characteristics of four laccases from different basidiomycetes. Biochimie 86, 693-703. doi:10.1016/j.biochi.2004.08.005

Shumakovich, G. P., Shleev, S. V., Morozova, O. V., Khohlov, P. S., Gazaryan, I. G., and Yaropolov, A. I. (2006). Electrochemistry and kinetics of fungal laccase mediators. Bioelectrochemistry 69, 16-24. doi:10.1016/j.bioelechem.2005.10.001

Sigoillot, C., Record, E., Belle, V., Robert, J. L., Levasseur, A., Punt, P. J., et al. (2004). Natural and recombinant fungal laccases for paper pulp bleaching. Appl. Microbiol. Biotechnol. 64, 346-352. doi:10.1007/s00253-003-1468-3

Siqueira, G., Várnai, A., Ferraz, A., and Milagres, A. M. (2012). Enhancement of cellulose hydrolysis in sugarcane bagasse by the selective removal of lignin with sodium chlorite. Appl. Energy 102, 399-402. doi:10.1016/j.apenergy.2012.07.029

Sjostrom, E. (1993). Wood Chemistry: Fundamentals and Applications. San Diego, CA: Academic Press.

Solano, F., Garcia, E., Perez, D., and Sanchez-Amat, A. (1997). Isolation and characterization of strain MMB-1 (CECT 4803), a novel melanogenic marine bacterium. Appl. Environ. Microbiol. 63, 3499-3506.

Solomon, E. I., Sundaram, U. M., and Machonkin, T. E. (1996). Multicopper oxidases and oxygenases. Chem. Rev. 96, 2563-2606. doi:10.1021/cr950046o

Srebotnik, E., and Hammel, K. E. (2000). Degradation of nonphenolic lignin by the laccase/1-hydroxybenzotriazole system. J. Biotechnol. 81, 179-188. doi:10.1016/ S0168-1656(00)00303-5

Srebotnik, E., Messner, K., and Foisner, R. (1988). Penetrability of white rotdegraded pine wood by the lignin peroxidase of Phanerochaete chrysosporium. Appl. Environ. Microbiol. 54, 2608-2614.

Sterjiades, R., Dean, J. F., and Eriksson, K. E. (1996). Laccase from sycamore maple (Acer pseudoplatanus) polymerizes monolignols. Plant Physiol. 9, 11621168.

Tamminen, T., Kleen, M., Ohra-Aho, T., and Poppius-Levlin, K. (2003). Chemistry of mediated-laccase delignification analyzed by pyrolysis-GC/MS. J. Pulp Pap. Sci. 29, 319-323.

Teeradakorn, S., Talawanich, Y., Suzuki, I., Pinphanichakarn, P., Fujiyama, K., Sekiand, T., et al. (1998). Characterization of Streptomyces D3 derived from protoplast fusion between Streptomyces cyaneus 190-1 and Streptomyces griseoruber 42-9. World J. Microbiol. Biotechnol. 14, 565-570. doi:10.1023/A:1008841626968

Thakker, G., Evans, C., and Rao, K. K. (1992). Purification and characterization of laccase from Monocillium indicum Saxena. Appl. Microbiol. Biotechnol. 37, 321-323. doi:10.1007/BF00210986

Ullrich, R., Huong, L., Dung, N., and Hofrichter, M. (2005). Laccase from the medicinal mushroom Agaricus blazei: production, purification and characterization. Appl. Microbiol. Biotechnol. 67, 357-363. doi:10.1007/s00253-004-1861-6

United Nations. (2012). Forest Products Annual Market Review 2011-2012. New York: UNECE/FAO, United Nations.

Viikari, L., Ranua, M., Kantelinen, A., Sundquist, J., and Linko, M. (1986). “Bleaching with enzymes," in Proceedings of the 3rd International Conference of Biotechnology on Pulp and Paper Industry (Stockholm, Sweden), 67-69.

Ward, G., Hadar, Y., Bilkis, I., and Dosoretz, C. G. (2003). Mechanistic features of lignin peroxidase-catalyzed oxidation of substituted phenols and 1,2dimethoxyarenes. J. Biol. Chem. 278, 39726-39734. doi:10.1074/jbc.M303918200
Weihua, Q., and Hongzhang, C. (2008). An alkali-stable enzyme with laccase activity from entophytic fungus and the enzymatic modification of alkali lignin. Bioresour. Technol. 99, 5480-5484. doi:10.1016/j.biortech.2007.11.014

Widsten, P., and Kandelbauer, A. (2008). Laccase applications in the forest products industry: a review. Enzyme Microb. Technol. 42, 293-307. doi:10.1016/j. enzmictec.2007.12.003

Wong, D. S. (2009). Structure and action mechanism of ligninolytic enzymes. Appl. Microbiol. Biotechnol. 157, 174-209. doi:10.1007/s12010-008-8279-Z

Xu, F. (1999). "Recent progress in laccase study: properties, enzymology, production, and applications," in Encyclopedia of Bioprocess Technology: Fermentation, Biocatalysis, Bioseparation, eds M. C. Flickinger and S. W. Drew (New York: John Wiley \& Sons, Inc.), 1545-1554.

Xu, F., Shin, W., Brown, S., Wahleithner, J., Sundaram, U., and Solomon, E. (1996). A study of a series of recombinant fungal laccases and bilirubin oxidase that exhibit significant differences in redox potential, substrate specificity, and stability. Biochim. Biophys. Acta Protein Struct. Mol. Enzymol. 1292, 303-311. doi:10.1016/0167-4838(95)00210-3

Xu, H., Lai, Y. Z., Slomczynski, D., Nakas, J. P., and Tanenbaum, S. W. (1997) Mediator-assisted selective oxidation of lignin model compounds by laccase from Botrytis cinerea. Biotechnol. Lett. 19, 957-960. doi:10.1023/A:1018378813312

Yang, J., Chen, L., Wang, L., Zhang, W., Liu, T., and Jin, Q. (2007). TrED: the Trichophyton rubrum expression database. BMC Genomics 8:250. doi:10.1186/14712164-8-250

Yaropolov, I., Skorobogatko, V., Vartanov, S., and Varfolomeyev, D. (1994). Laccaseproperties, catalytic mechanism, and applicability. Appl. Biochem. Biotechnol. 49, 257-280.

Yoshida, H. (1883). LXIII. - chemistry of lacquer (Urushi). Part I. Communication from the chemical society of Tokio. J. Chem. Soc. Trans. 43, 472-486. doi: $10.1039 /$ ct8834300472

Zhang, L., Henriksson, G., and Gellerstedt, G. (2003). The formation of [small beta][small beta] structures in lignin biosynthesis-are there two different pathways? Org. Biomol. Chem. 1, 3621-3624. doi:10.1039/b306434d

Zhu, X., and Williamson, P. R. (2004). Role of laccase in the biology and virulence of Cryptococcus neoformans. FEMS Yeast Res. 5, 1-10. doi:10.1016/j.femsyr.2004. 04.004

Conflict of Interest Statement: The authors declare that the research was conducted in the absence of any commercial or financial relationships that could be construed as a potential conflict of interest.

Received: 11 February 2014; paper pending published: 02 March 2014; accepted: 17 March 2014; published online: 31 March 2014.

Citation: Christopher LP, Yao B and Ji Y (2014) Lignin biodegradation with laccase-mediator systems. Front. Energy Res. 2:12. doi: 10.3389/fenrg.2014.00012

This article was submitted to Bioenergy and Biofuels, a section of the journal Frontiers in Energy Research.

Copyright (c) 2014 Christopher, Yao and Ji. This is an open-access article distributed under the terms of the Creative Commons Attribution License (CC BY). The use, distribution or reproduction in other forums is permitted, provided the original author(s) or licensor are credited and that the original publication in this journal is cited, in accordance with accepted academic practice. No use, distribution or reproduction is permitted which does not comply with these terms. 